\title{
胸椎後縦勒带骨化症に対する手術法
}

\section{一特に手術用顕㣲鏡下での前外側アプローチによる骨化巣削 除法の有用性について—}

\section{Surgiery for Thoracic OPLL}

-Usefulness of Microsurgical Resection of Ossified Lesion through Transthoracic

\section{Anterolateral Approach-}

花 北順 哉

Junya Hanakita, M.D.

\section{Key words}

thoracic OPLL, surgery, transthoracic approach

\section{はじめに}

脊髄・春椎疾患に対する数多くの手術の中で，胸椎後 縦勒带骨化に対する手術は最も難易度の高い手術であ る1)。このように手術の難易度を高めている理由として 以下の事項が考えられる。

まず第一に，同じ後縦勒带骨化という病態でありなが ら，より発生頻度が高い䅡椎後縦勒带骨化においては有 用である後方除圧術（椎弓切除術・椎弓形成術）が, 胸 椎が生理的後弯形成をなしているがために通常は無効で あるか，脊柱の後方支持要素を破壊してしまうために脊 柱の後弯が増強してしまい, 時には結果的に脊髄症状を 悪化させてしまう危険を孕んでいるからである ${ }^{1-3)}$.

第二の理由としては，骨化巣削除を目的にした手技に おいて骨化巣に後側方からアプローチした場合には，骨 化巣削除操作の全過程を直視下に行うことができず，一 部盲目的な操作となったり, 骨化巣削除の段階で脊髄を 過度に毫引しながら操作を続ける結果, 脊髄へのダメー ジが生じることとなる。このため，骨化巣を直視下に削 除するためには病巣に対して前方あるいは前外側からの アプローチが必要となるが, これを行うためには, 胸椎
レベルでは胸骨縦割法あるいは開胸術といった脳神経外 科医にはなじみのない特殊な手技が必要となり，術後管 理を含めてこの手技を習得するか，あるいは胸部外科医 との共同手術が必要となる4 7).

第三の理由としては，胸椎後縦勒帯骨化という病態が きわめてまれなものであるために，この疾患に対する手 術を経験する機会が限られており，そのためにこれに対 する手術手技を伝達することがなかなか困難な点であ $ろ^{1,8,9)}$.

筆者は現在までの約 30 年間，脊髄・脊椎外科分野で 執刀医として過ごしてきたが，自ら治療にあたった胸椎 後縦勒带骨化は 28 症例である。本稿ではこれらにおい て経験したことを紹介するとともに，胸椎後縦勒带骨化 に対する手術手技のポイントにつき記載する.

\section{対象と方法}

$1983 \sim 2013$ 年の 30 年間に筆者が手術を行った胸椎後 縦勒带骨化の 28 例を対象とした。症例の年齢・性別 · 骨化巣のレベル・採用した術式・術後成績・合併症につ いて検討した。 
Table 1 骨化巣削除を目指した症例

\begin{tabular}{cccclcccc}
\hline $\begin{array}{c}\text { Case } \\
\text { No }\end{array}$ & $\begin{array}{c}\text { Age } \\
\text { (years) }\end{array}$ & Sex & $\begin{array}{c}\text { Level of } \\
\text { OPLL }\end{array}$ & Operative procedure & $\begin{array}{c}\text { Intraoperative } \\
\text { CSF leakage }\end{array}$ & $\begin{array}{c}\text { Nurick grade } \\
\text { preop. }\end{array}$ & Date of \\
postop. & operation \\
\hline 1 & 67 & M & C7-T1 & Cervical ant. app. & - & 4 & 3 & 1999.9 \\
2 & 32 & F & T1-2 & Sternum splitting app. & - & 3 & 0 & 1995.5 \\
3 & 58 & F & T1-3 & Sternum splitting app. & + & 4 & 3 & 1998.12 \\
4 & 58 & F & T1-3 & Sternum splitting app. & - & 3 & 1 & 1992.11 \\
5 & 58 & F & T1-6 & Stenum splitting app. & + & 3 & 2 & 2012.2 \\
& & & & Transthoracic app. & + & 2 & 1 & 2012.3 \\
6 & 39 & F & T2-3 & Sternum splitting app. & + & 4 & 5 & 1983.8 \\
7 & 39 & F & T2-3 & Posterolateral app. & - & 4 & 4 & 1983.5 \\
8 & 46 & F & T3-4 & Transthoracic app. & + & 3 & 1 & 2011.3 \\
9 & 77 & F & T3-6 & Transthoracic app. & + & 3 & 1 & 2006.8 \\
10 & 57 & F & T3-6 & Transthoracic app. & - & 3 & 0 & 2008.5 \\
11 & 59 & M & T3-7 & Posterolateral app. & + & 4 & 2 & 1990.9 \\
12 & 49 & F & T3-8 & Posterolateral app. & + & 3 & 5 & 1991.3 \\
13 & 70 & F & T4-5 & Transthoracic app. & - & 3 & 1 & 1996.12 \\
14 & 56 & M & T5-6 & Posterolateral app. & - & 3 & 5 & 2004.6 \\
15 & 75 & F & T5-6 & Transthoracic app. & - & 3 & 1 & 2002.12 \\
16 & 50 & F & T5-7 & Posterolateral app. & - & 3 & 2 & 2001.4 \\
17 & 68 & F & T5-8 & Posterolateral app. & - & 3 & 0 & 1997.5 \\
18 & 45 & M & T5-8 & Transthoracic app. & + & 3 & 0 & 2004.11 \\
19 & 72 & F & T8-9 & Transthoracic app. & - & 3 & 1 & 2002.8 \\
20 & 63 & F & T8-11 & Posterolateral app. & + & 4 & 3 & 2002.1 \\
21 & 59 & M & T12-L1 & Posterolateral app. & + & 3 & 0 & 1994.7 \\
\hline
\end{tabular}

Table 2 骨化巣削除は行わずに後方減圧のみを行った症例

\begin{tabular}{cccccccc}
\hline $\begin{array}{c}\text { Case } \\
\text { No }\end{array}$ & $\begin{array}{c}\text { Age } \\
\text { (years })\end{array}$ & Sex & $\begin{array}{c}\text { Level of } \\
\text { OPLL }\end{array}$ & Operative procedure & $\begin{array}{c}\text { Intraoperative } \\
\text { CSF leakage }\end{array}$ & $\begin{array}{c}\text { Nurick grade } \\
\text { preop. }\end{array}$ & $\begin{array}{c}\text { Date of } \\
\text { postop. }\end{array}$ \\
operation
\end{tabular}

\section{採用された術式}

本シリーズで行われた術式は大きく分けて，何らかの アプローチにより骨化巣削除を目指した群（骨化巣削除 群) と骨化巣削除は目指さずに椎弓切除・椎弓形成術な どの間接的除圧を目指した群（後方除圧群）との 2 群に 分けられた。骨化巣削除群には 21 例, 後方除圧群には 7 例が属していた（Table 1, 2).

\section{結 果}

術後の成績は，改善を示したものが 24 例，不変 1 例 であったが， 3 例では高度の対麻痺が生じた。術中の髄 液漏出は 11 例に認められ，うち 1 例は術後 40 日間ほど 多量の胸腔内髄液貯留が残存した。術中に髄液漏出を認 めた症例では, 漏出部位を脂肪片でパックし, 腰部の spinal drainage の留置を 5 7 日間行った。フィブリン糊製
版が導入されて以降は，脂肪片とフィブリン糊を多層に 用い漏出部位を十分にふさぐ操作を行った。

\section{考 察}

胸椎レベルにおいて胸髄の腹側に存在する病変として は，胸椎椎間板ヘルニア・胸椎椎体腫瘍・胸髄腫瘍・胸 椎後縦勒带骨化・胸髄動静脈奇形, 胸髄へルニアなどが ある。これらの病態に対するアプローチとしては Table 3 のようなさまざまなものが提唱されてきた。胸椎後縦 勒帯骨化に対してこれらのアプローチを採用した場合の それぞれの利点・欠点・手術のポイントにつき記載す る.

\section{1 椎弓切除術・椎弓形成術}

胸椎後縦勒带骨化において, これら後方除圧法が適応 となる症例は, 後縦勒带骨化の同一病变レベルに黄色勒 
Table 3 胸䯣腹側病変に対する各種アプローチ

1. Conventional anterior approach

2 . Anterior approach with sternal splitting

3. Transthoracic anterolateral approach

4. Retropleural retroperitoneal approach

5. Posterolateral approach

6. Extensive cervicothoracic laminectomy or laminoplasty without resection of ventral lesion

7. Combined anterior \& posterior approach

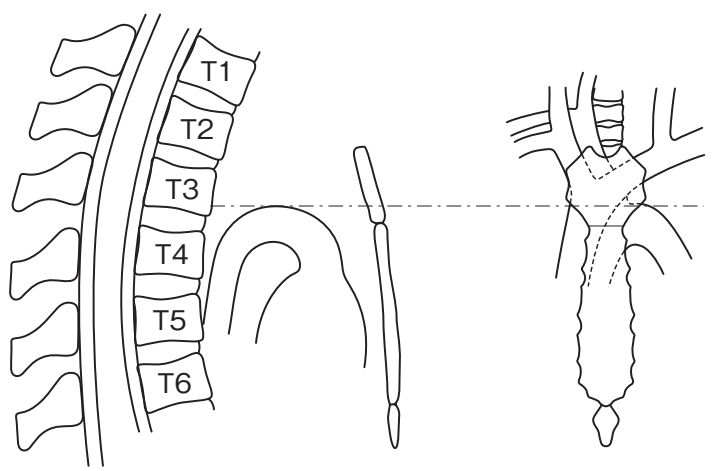

Fig. 2 胸骨縦割法における椎体高位と大血管・胸骨の位置関係 を示す模式図

術野は狭く, 深いものであるが, 椎体には真正面から到達可能であ るために，術中のオリエンテーションは容易である.

带骨化などの後方圧迫要素が合併している症例である. このアプローチの利点としては，後縦勒帯骨化の病変が どの部位にあっても，またどれほど広い範囲に及んでい ても応用可能な点である。

胸椎は生理的後弯を呈しているために，胸椎レベルで の後方除圧の効果はそしいと記載したが，この久点を解 決するために, 上位䅡椎から全胸椎, 下位腰椎までに及 ぶ広範囲の椎弓形成術も提唱されている ${ }^{10)}$. この手術法 の欠点としては，前述したごとく，たとえ再建するとし ても棘突起・椎弓に付着する強固な後方支持組織である 筋・勒帯群を損傷してしまうために, 胸椎の alignment が悪化する懸念があることである。この胸椎 alignment の変化による脊髄への悪影響は, 術中に直ちに出現する ことが術中の各種の脊髄モニタリングにより報告されて いる2).このため, 後方除圧を行う場合には椎弓根スク リュー・ロッドを設置して, 胸椎の alignment の後弯位 の矯正あるいは後弯増強の防止に努めることが勧められ る.また椎弓切除の操作に先立ち椎弓根スクリュー・ ロッドを設置しておくことの重要性が指摘されてい $ろ^{2)}$.

\section{2 下位頚椎・上位胸椎前方到達法}

頚椎前方到達法は脳神経外科医にはなじみのある到達 法である。これを下方まで延長することにより, 症例に

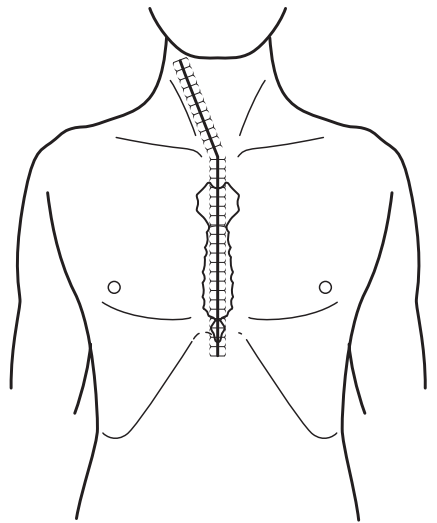

Fig. 1 胸骨縦割法に用いる皮䖉 切開線

よっては $\mathrm{C} 7 / \mathrm{T} 1$ 椎間板レベルまでは到達可能である.こ れ以下のレベルでは胸骨が邪魔となり骨化巣削除の操作 はできない。

胸椎後縦勒带骨化はこのレベルに生じることはそれほ ど多くないので，このアプローチで対処しうる骨化症の 症例はごく限られている11.

\section{3 胸骨縦割法を用いるアプローチ}

このアプローチでは, $\mathrm{T} 3 / 4$ の椎間板レベルまでは到達 可能であり, 骨化巣が $\mathrm{T} 1 \sim \mathrm{T} 3 / 4$ レベルに存在している 場合に採用される術式である ${ }^{4,9,11 \sim 13)}$. 胸骨縦割法では, 胸骨の縦割操作の際に縦隔内臓器の損傷を避けること, 胸骨の再建を行うことが必要となる。筆者はこの操作を 単独で行うことはなく, 全例胸部外科医あるいは心臟外 科医との共同手術を行ってきた。その理由の 1 つは, や はり縦隔内・胸腔内臟器の扱いにはそれぞれいくつかの ポイントがあり，彼らのほうがはるかにわれわれよりも 習熟しているからである。もう 1 つの理由としては, こ れら胸部外科医と共同手術を行うことにより，脊椎外科 に対して脳神経外科医が積極的に取り組んでいる姿勢を 彼らに認知してもらうことである。この宣伝効果は彼ら が扱う癌患者が脊椎転移をきたした場合に，まずはわれ われに相談するという形で実を結ぶこととなる。

胸骨縦割法では術野に気管・食道だけでなく大血管群 が存在し，かつ T1 から T3/4 レベルになるに従い術野 は深くなっていく．このアプローチで到達可能な骨化巣 レベルは T3/4 までであり，これ以下のレベルは大動脈 弓が邪魔となり到達できない (Fig. 1, 2)。また骨移植, 椎体プレートを設置する場合の操作可能なレベルは T3 椎体下縁レベルである ${ }^{11)}$ 。この到達法は, 上述のごとく 術野の深さ，大血管群の存在などいくつかの問題はある が骨化巣削除の操作は真正面から直視下に行えるもので 
あり, 澒椎後縦勒带骨化巣削除と同様の操作が行える点 が最大の利点である。

\section{4 後外側到達法を用いるアプローチ}

胸椎後縦勒带骨化巣を後外側から削除する方法は信州 大学整形外科の大塚により提唱されたアプローチであり 大塚法と呼ばれている ${ }^{14)}$. 胸髄腹側に存在する骨化巣に 対して, 通常の椎弓切除の幅を左右に拡大し, 椎間関節 · 椎弓根部・横突起やこれに付着する肋骨頭を削除し, 極 力後外側から到達する方法である。この到達法を筆者も 8 例で試みたが, そのうち 2 例では完全対麻瘏となった。 軽度の骨化巣病変であればこの方法で削除可能な場合も あると考えるが，骨化巣が厚く硬膜の骨化を伴っている もの, 胸䯣がブーメラン状に変形しているものでは, こ のアプローチを行った場合, どうしても骨化巣削除操作 が盲目的なものとなりうること, 硬膜の骨化を伴う場合 には骨化巣削除の段階で, 硬膜欠損・くも膜損傷・䯣液 漏出をきたしやすいこと, 髄液が漏出した硬膜管はバッ ファーとしての髄液が消失しているために硬膜管の軽度 の劧引操作でももろに脊髄を牽引することとなり脊髄障 害が生じやすいことが, この術式の大きな欠点であ $ろ^{1,9)}$. このアプローチでは左右から到達し正中部の骨化 巣を盲目的な操作により腹側に落とし込むテクニックが 推奨されているが，骨化巣が厚く残った場合にはあまり 十分な除圧効果が得られないこととなる。現段階では, 筆者はこの大塚法は胸椎後縦勒带骨化に対しては不向き の到達法であると考えている。このアプローチの適応と なる病態としては, 胸椎レベルの比較的軟らかい病変, たとえば胸椎椎間板へルニアや，胸椎への転移性腫瘍を 姑息的に摘出する場合などである ${ }^{15 \sim 19)}($ Fig. 3).このア プローチは, 黄色勒帯骨化などの後方病変が合併してい る場合には有用であり, また病変レベルがいくら長い距 離にわたっても適応しうる点が利点である。また何らか の後方 instrumentationの設置が容易に行えることもこ の到達法の利点である.

\section{5 開胸術による前外側到達法を用いるアプロー チ $6,9,20 \sim 22)$}

骨化巣を直視下に摘出しうる方法としては, 開胸術を 行い手術用顕微鏡下操作による前外側到達法が最も優れ た方法である ${ }^{9)}$. 筆者はこのアプローチを現在までに 8 例に行っている. 現段階では T4 以下の胸椎後縦勒帯骨 化に対しては, 骨化巣を直視下に摘出しうるものであり, 何らかの椎体固定や内固定器具の設置も必要としないこ とから，この手術法が最適の方法と考えている. 以下の ところでは, このアプローチの具体的方法・ポイントに つき詳述する。

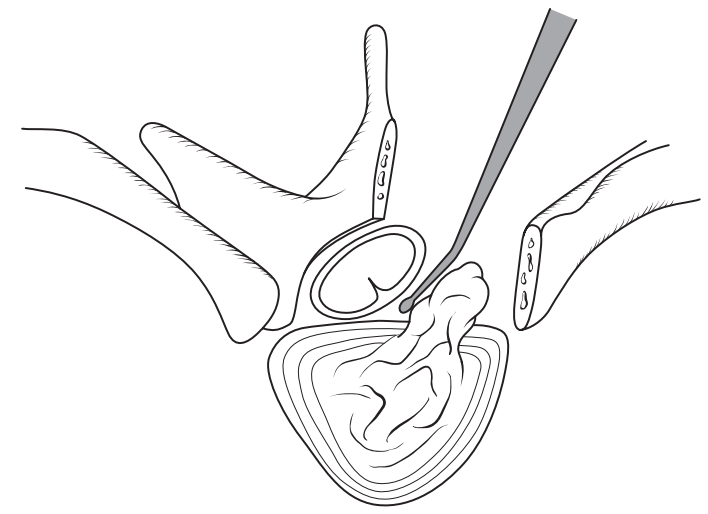

Fig. 3 胸檤腹側病変（胸椎椎間板ヘルニア）に対する後外側到達 法の模式図

このアプローチでは, 術中に脊髄を牽引するような操作は避ける必 要がある. 椎弓・椎間関節・椎弓根部を十分に削除し, 極力後外側 からアプローチする.図のような逆向きにカーブした鋭匙を使用す る. 椎間板へルニアや転移性椎体腫瘍などが最も良い適応である. 後縦勒带骨化巣などの硬く厚みのある病変には不向きなアプロー チである。

\section{1．体位および麻酔}

筆者は左を下にした側臥位を採用している。右側での 開胸術を好む理由は，椎体に対して前外側からアプロー チする本術式では, 左開胸にてアプローチすると椎体の 左前面に大動脈が位置しており，椎体削除の際に邪魔に なるためである．椎体掘削は椎体に対して真側面から到 達することがポイントであるために，体位設定の段階で 患者の躯幹・胸郭・骨盤に数個の支持板やスポンジを置 き，患者の姿勢が正確に側臥位にあることを確認する。 また術中に手術台を左右に 15 度程度は傾斜させる必要 があるので，あらかじめ手術台を傾けても患者の体がず り落ちない位置にしっかりと固定されていることを確認 しておく. Adamkiewicz 動脈の損傷を懸念して左開胸を 勧める報告もみられるが，筆者が経験した開胸を伴うア プローチはすべて右開胸にて行いこの動脈の損傷と思わ れる症例には遭遇していないために，前述した理由によ り右開胸下での到達がふさわしいと考えている。術中， 右肺は虚脱させるために挿管チューブは左右分離換気が 可能なものを用いる.

\section{2. 右開胸の位置および開胸操作}

骨化巣病変の位置にもよるが，開胸レベルは第 5 ある いは第 6 肋間にて行う。皮膚切開線は肋間に沿って行 い, 背側はほぼ正中に達するまでの大きな皮膚切開を置 く、開胸し右肺を虚脱させるまでの操作は胸部外科医が 行う. 通常は第 4 肋骨あるいは第 5 肋骨を切断する。開 胸された腔は術者の両コブシがすっぽりと入る程度の大 きなものとする。これは後ほど，手術用顕微鏡下に骨化 


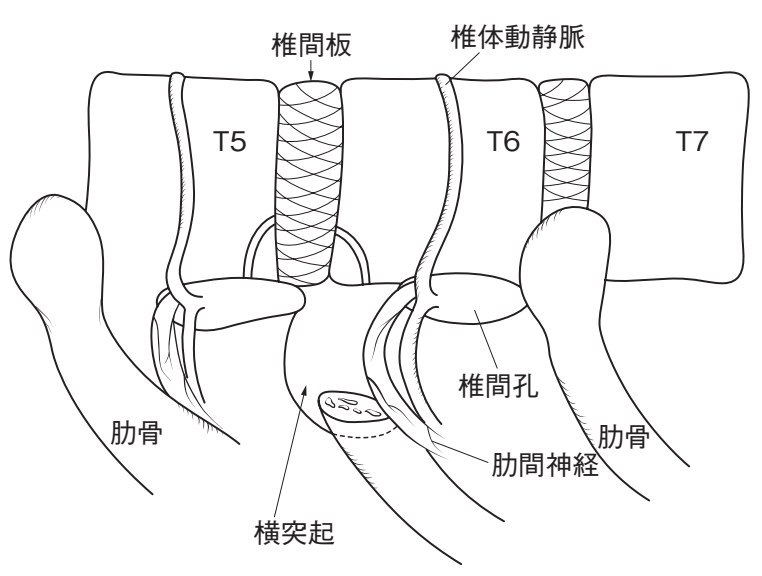

Fig. 4 右開胸術による前外側到達法の模式図

T5，T6，T7 椎体側面が露出されており，T5-T6 椎体に付着する肋 骨頭はすでに切除されている.胁骨頭の切除は骨化巣の広がりによ り数個切除する. 胁骨が付着する部分を中心に，椎体後面を幅 10 $\mathrm{mm}$, 深さ $20 \mathrm{~mm}$ を目標に骨化巣の長さに応じて椎体削除を行う.

巣をダイヤモンドドリルにて削除していく操作段階に て, 重要なポイントとなってくる点である.

\section{3. 肋骨頭の削除と椎体側面の露出}

この段階で胸部外科医から操作を受け継ぎ，これ以降 は脳神経外科医が手術用顕微鏡下での術操作を行う。最 初の段階では術者は患者の背側に立ち, 助手が腹側に立 つ. 通常は第 4 肋骨あるいは第 5 肋骨頭を先端から 2 $\mathrm{cm}$ 程度のところまでドリルにて削除する．胁骨頭は上 位・下位の椎体側面と関節面を形成しており，この部に 椎間板レベルが存在するために，肋骨頭の完全な削除は その後の術野のオリエンテーションをつけるのに有用で ある (Fig.4)。骨化巣の病変の長さに応じて, 肋骨頭は 数個削除する. 椎体の側面に付着する前縦勒带を電気入 スにて凝固しつつ剝離していくが，これはほほ椎体の前 面正中部分まで行う。この勒帯剝離操作の段階で，椎体 真ん中部分を横走する椎体動静脈がみられるが，これは 血管クリップにて完全に止血後切断する.この椎体に対 するこれらの操作は骨化巣の範囲に応じて，1～数椎体 にわたって行う.

\section{4. 椎体に側溝を作成する}

患者の体位が, 真側臥位であること, 手術台が水平位 に保持されていることを再度確認後, 椎体削除の操作に 移る. 先ほど切除した肋骨頭部分を観察すると椎間孔お よび椎体後縁が確認されるので，これを基準としてこの 椎体後縁から $10 \mathrm{~mm}$ までのところを目安に側溝作成を 行う（Fig. 5)。この際ドリルを進める方向は水平位にあ る手術台に垂直に，すなわち患者の椎体側面に対して垂 直になるように真っ直ぐ進めることが最も肝心である. あらかじめ患者の罹患椎体の横幅を CT scan 上計測し

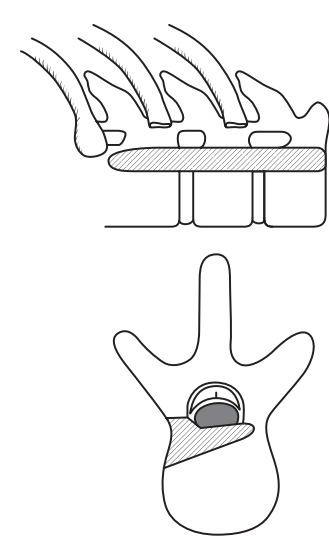

Fig. 5 手術用顕微鏡下での椎体前外側到達法における椎体の掘 削範囲を示す模式図

ておくとよいが，通常はこの側溝は幅が $10 \mathrm{~mm}$, 深さが $20 \mathrm{~mm}$ のものを作成する。この溝の長さは削除すべき骨 化巣の長さにより規定される。この段階のポイントとし ては，ドリルの進入方向を間違わないことであり，その ためには患者のポジションがくれぐれも正しい側卧位に あるように体位設定を行うことが最重要である。この時 点では, 術者からみて溝の手前側, すなわち脊柱管側に 一部勒帯の骨化部分が露出されてくるが，この段階では まだ骨化巣の削除操作は積極的には行わない。ほぼ必要 な椎体数におよぶ側溝が椎体後方部分に作成された段階 で，一度十分に右肺の換気を行い，術後の無気肺発生を 予防する。ここで術者の立ち位置が患者の腹側に移動す る。

\section{5. 骨化巣の確認および手術用顕微鏡下での骨化巣削 除操作}

再び右肺を完全に虚脱させ，椎体掘削操作を続ける． ドリルは超ロングのダイヤモンドドリルを装着し, 助手 に十分な吸引操作を依頼しつつドリルをしっかりと両手 で保持して削除を進める。手術台を十分に左右へと傾け つつ，骨化巣が全長にわたりほぼ均一の厚さになるよう に心がけながら，削除操作を進める。この際，骨化巣の 削除は必ず直視下に行う必要がある。この操作のポイン トとしては，術野は十分な洗浄と吸引により，クリアな 状態が保たれるようにすることが肝要で，血だらけの術 野で闇雲にドリルを回すような操作は厳に慎むべきであ る。また骨化巣はドリルを押し付けながら削るのではな くて，ドリルの刃先の側面でなでるような感覚で薄くし ていくことが望ましい，骨化巣は通常の場合硬膜自体の 骨化を伴っているので，理想的には骨化巣は削除するよ りも薄くして浮き上がらせる，いわゆる浮上法にて処置 することが针められる。この浮上の感覚は, 削除を進め 
Fig. 6 術前の CT scan

a：症例 18 (Table 1) の術前 CT scan 矢状断再構成画 像.

b : 症例 18 (Table 1) の術前 CT scan（T6 レベル）水平 断像.

c : 症例 8 (Table 1) の術前 CT $\operatorname{scan}(\mathrm{T} 4$ レベル) 水平断像.
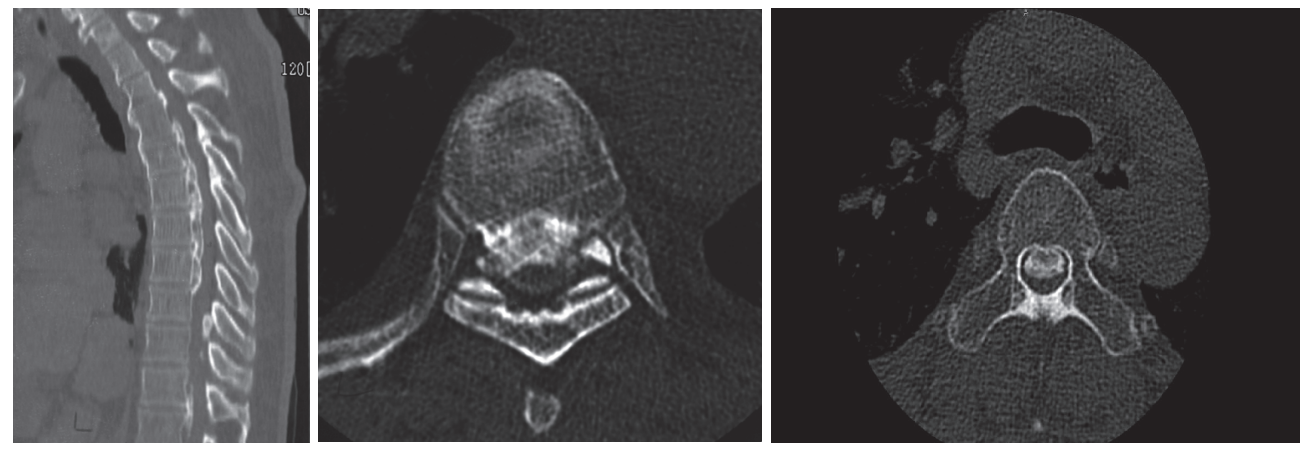

Fig. 7 術後の CT scan

椎体の削除範囲を示す。骨化巣は削除されている。こ の術式では, 脊柱管の大部分が温存されるために, 椎 体内への骨移植や内固定器具の設置は必要でない.

a：症例 18 (Table 1) の術後 CT scan（T6 レベル） の水平断像.

b : 症例 8 (Table 1) の術後 CT scan（T4 レベル）の 水平断像.
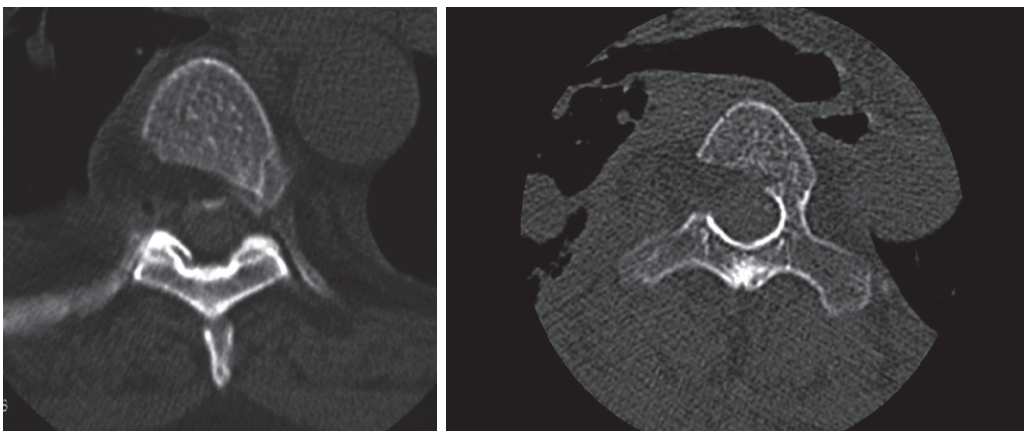

るに従い骨化した硬膜が徐々に拍動してくる様子で感じ 取ることができる。ただ数力所で硬膜欠損・くも膜損 傷・髄液漏出がみられることはしばしばである。この場 合には, 術操作の最終段階で脂肪片・フィブリン糊によ る綿密な漏孔閉鎖の操作を行う。骨化巣削除の操作は, 手術台を左右へとさまざまに傾けながら，全工程を直視 下に行うことを肝に銘じながら慎重に進めることが最も 肝心である。

\section{6. 髄液漏出部の処置・内固定操作・閉胸操作}

骨化巣部が良好に浮上され，良好な硬膜拍動が全長に わたり確認された段階で除圧操作が終了する。髄液漏出 が認められた場合には前述のごとく, 漏出部にフィブリ ン糊を塗布し，脂肪片をあてる．この操作を 2 層あるい は 3 層にわたり行う。十分な長さの胁骨片が採取された 場合にはこの胁骨片を椎体の側溝に挿入しておいてもよ い. 閉胸操作終了後, 腰椎レベルにおいてスパイナルド レナージを設置し，これを $5 \sim 7$ 日間留置する.

筆者の手術操作であれば椎体掘削の幅は $10 \mathrm{~mm}$ であ り, 肋骨頭を含め脊柱の左側の支持組織は無傷で温存さ れているために，骨移植や何らかの椎体固定のための内 固定器具の設置は不要である (Fig. 6, 7)。術後最長 8 年間 follow-up しているが，胸椎の後弯位の増強をきた した症例はない.

術野の止血操作を確認後, 胸部外科医により閉胸操作 が行われる。胸腔ドレナージは原則として 3 日間留置さ

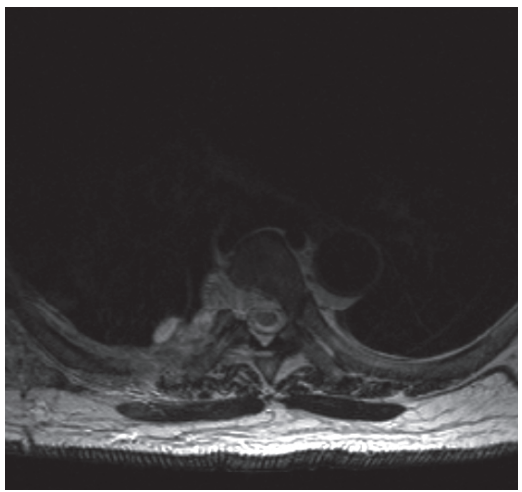

Fig. 8 術後の MRI

春髄の十分な除圧が得られている様子を示す。症例 18（Table 1) の術後 MRI（T4レベル）.

れるが，䯣液漏をきたした症例ではあまり過度の陰圧は 加えないように設定する．開胸創が大きいために術後の 側胸部痛を訴えることが多いので，十分な術後鎮痛対策 を考慮する。

\section{6 前方・後方合併到達法を用いる方法}

この手術法は，金沢大学整形外科の富田らにより考案 された術式である ${ }^{23,24)}$ 。筆者はこの手術法を行った経験 はない，黄色勒帯骨化などの後方要素が合併した症例に おいて，前方・後方の両者の骨化巣を削除するには適し た方法であると考える．彼らの工夫で優れた点は，後方 からアプローチする段階で，後方から椎体にあらかじめ 
溝を作成しておき, 後ほど開胸して前方から椎体削除を 加える際のメルクマールにしている点である。この前後 合併到達法は, 骨化巣を徹底的に削除するという点では 優れた方法であるが, 彼らの削除法では椎体のかなりの 部分が掘削されており, また後方支持要素も椎弓・束突 起を含めかなりの部分削除されているために, 強固な前 方・後方の内固定器具を用いた椎体固定術を併施する必 要がある。このように, 侵襲の大きな術操作になってい る点は本術式の欠点である。

\section{7 胸椎後縦勒帯骨化に対する手術の手術成績・問 題点・課題}

今まで述べてきたごとく, 胸椎後縦勒带骨化に対する 手術はさまざまな理由によりすべての脊椎・脊髄手術の 中で難易度が最高レベルに高いものである ${ }^{1,9)}$. 本稿にて 紹介したごとくいくつかの術式が提唱されているが，そ れはとりも直さずいまだ最適な手術法であるとのコンセ ンサスが得られていないことを反映していると思う。筆 者も長年にわたり脊髄・春椎外科に取り組んできたが, それでも自ら経験した手術症例は 28 例に過ぎない. 昨 今はやりの EBM に基づいた最適の手術法は何であるか とのエビデンスは当分のところ得られそうにない病態で あり，この症例に遭遇した外科医が苦しみながら挑戦す ることを強いられる状況が当分は今後も続くと予想され る、いくつかの学会での報告や論文をみていると, 後方 の椎弓形成術と後方 instrumentation を加えた方法が最 近は好まれているようである2)。しかしながら，骨化巣 病変が短いながら嘴状に脊髄を圧迫している症例に対し ても後方の広範囲の除圧・長い instrumentation にて対 応している報告をみると, こういう症例こそ, 今回詳し く紹介した開胸による手術用顕微鏡下の前方除圧術が最 適の手術法であると思える。現段階では筆者個人は, 開 胸という侵襲の大きな術操作を必要とするが手術用顕微 鏡下に行う骨化巣削除・内固定なしという方法が胸椎後 縦勒带骨化に対してべストであろうと考えている9 . こ れほど難易度の高い, かつ術中の春髄損傷が生じる危険 が高い手術に扔いては, 術中の脊髄モニタリングの重要 性が提唱されている。 今回の筆者の症例はすべてモニ夕 リングなしに行われた手術であった，今回のシリーズで 悪化した症例で，モニタリングを使用していればあるい は術後の悪化が防げた可能性がある。しかしながら術前 の対麻痺症状が重症であればあるほど術中のモニタリン グの測定が困難であり，モニタリングへの信頼性が低下 するとされている，開胸にて骨化巣削除を行った症例は ここ 10 年間は悪化症例はなかった. 手術の成績はモニ タリングの使用・不使用に左右されるというよりも, や
はり術者の技量の絶えざるスキルアップによりもたらさ れているのであろうと考えている.

\section{まとめ}

胸椎後縦勒带骨化に対する自験例をもとにこの病態に 対する手術法・それのポイントにつき記載した。最適の 手術法がどれであるのかに関してはいまだコンセンサス が得られていない病態であり, われわれ脊髄・春椎外科 医にとっては最大の難敵である.

今後に続く人々の飽くなきチャレンジを期待するもの であり，その際に本稿がいささかでも役に立てば幸いで ある。

\section{文 献}

1）花北順哉：胸椎後縦勒带骨化症と脊椎症. 脳外誌 $4: 92-$ 97, 1995

2) Matsuyama Y, Yoshihara H, Tsuji T, et al : Surgical outcome of ossification of the posterior longitudinal ligament (OPLL) of the thoracic spine : Implication of the type of ossification and surgical options. J Spinal Disord Tech 18:492-497, 2005

3) Tokuhashi Y, Taki J, Matsuzaki H, et al : Effectiveness of posterior decompression for patients with ossification of the posterior longitudinal ligament in the thoracic spine : usefulness of the ossification-kyphosis angle on MRI. Spine $31: \mathrm{E} 26-30$, 2006

4) Cauchoix J, Binet JP : Anterior surgical approaches to the spine. Ann R Coll Surg Engl 21 : 237-243, 1957

5）花北順哉, 諏訪英行, 長安慎二, 他：胸椎後縦勒带骨化症, 胸椎椎間板ヘルニアの検討. Neurol Med Chir (Tokyo) 31: 936-942, 1991

6) Louis R : Surgery of the Spine. New York, Springer-Verlag, 1983, pp188-261

7) Albrand OW, Corkill GF : Thoracic disc herniation. Treatment and prognosis. Spine $\quad 4: 41-46,1979$

8) 藤村祥一：胸椎後縦勒带骨化症に対する前方進入前方除圧固 定術. 脊椎脊髄 15:105-111, 2002

9) Hanakita J : Microsurgery for thoracic OPLL : Assessing direct visualization and safe removability of the ossified lesion. J Spine Res 2 : 244-247, 2011

10) Tsuzuki N, Hirabayashi S, Abe R, et al : Staged spinal cord decompression through posterior approach for thoracic myelopathy caused by ossification of posterior longitudinal ligament. Spine 14:1623-1630, 2001

11) Hanakita J, Suwa $H:$ Sternal splitting approach to upper thoracic lesions located anterior to the spinal cord. Neurol Med Chir (Tokyo) 39:428-432, 1999

12) Otani K, Nakai S, Fujimura $Y$, et al : Surgical treatment of thoracic disc herniation using the anterior approach. J Bone Joint Surg Br 64:340-343, 1982

13) Alberico AM, Sahni S, Hall JA, et al : High thoracic disc herniation. Neurosurgery $19: 449-451,1986$

14）大塚訓喜：胸椎 OPLL に対する後方進入による前方除圧一 術式と成績. 日獨医報 32:119-128, 1987

15) Le Roux PD, Haglund MM, Harris AB : Thoracic disc disease : Experience with the transpedicular approach in twenty consecutive patients. Neurosurgery $33: 58-66,1993$ 
16) Patterson RH Jr, Arbit E : A surgical approach through the pedicle to protruded thoracic discs. J Neurosurg $48: 768^{-}$ 772,1978

17) Kojima T, Waga S, Kubo Y, et al : Surgical treatment of ossification of the posterior longitudinal ligament in the thoracic spine. Neurosurgery 34:854-858, 1994

18) Shaw B, Mansfield FL, Borges L : One-stage posterolateral decompression and stabilization for primary and metastatic vertebral tumors in the thoracic and lumbar spine. J Neurosurg 70:405-410, 1989

19) Simpson JM, Silveri CP, Simeone FA, et al: Thoracic disc herniation. Re-evaluation of the posterior approach using a modified costotransversectomy. Spine $18: 1872-1877,1993$

20) Hulme A: The surgical approach to thoracic intervertebral disc protrusions. J Neurol Neurosurg Psychiatry 23:133-137,
1960

21) Perot PL Jr, Munro DD : Transthoracic removal of midline thoracic disc protrusions causing spinal cord compression. J Neurosurg 31:452-458, 1969

22) Simeone FA, Rashbaum R: Transthoracic disc excision. In Schmiedeck HH, Sweet WH (eds) : Operative Neurosurgical Techniques. New York, Grune \& Stratton, 1982, pp1259-1268

23）富田勝郎，梅田真一郎：後縦勒带骨化症，黄色勒带骨化症に よる胸部脊髄症の手術方法一とくに合併例に対する一期的前 後除圧術. 臨整外 $23: 457-465 ， 1988$

24) Kawahara N, Tomita K : Circumspinal decompression for thoracic myelopathy due to combined ossification of the posterior longitudinal ligament and yellow ligament. J Jpn Spine Res Soc 12:450-456, 2001 